\title{
Ukrainian Memory and Victimhood \\ Narratives after the Second \\ World War \\ by Katrina Witt
}

\begin{abstract}
Memory can be selective and Ukrainian people are no exception. This paper examines the victimhood narrative of Ukrainians following the Second World War. Although they suffered greatly, through the war, the victimhood narrative denies their actions during the war. One component of this narrative involves ignoring Ukrainian involvement with Nazis in order to preserve their memory of their Great Heroes of WWII. Other aspects will also be considered.
\end{abstract}

The Second World War wreaked brutal havoc across Eastern Europe, especially in Ukraine. The Soviet Red Army, the German Wehrmacht, and local partisans fought over territory inhabited by ethnic Ukrainians, decimating the populations of ethnic groups in the area. Ukrainians, Poles, and Jews suffered horrible experiences during this time: Jewish communities were almost completely destroyed through emigration and genocidal purges, Poles were massacred, and Ukrainians were caught between the Soviet Union and Germany. Ukrainians sometimes fought with one side, sometimes with the other, and they were subject to victimization by both sides. Since the war, Ukrainians 
have tended to regard themselves as victims. They remember the horrors of that period and subjection to oppressive invading regimes. They also celebrate the members of the Organization of Ukrainian Nationalists (OUN) and Українська Повстанська Армія or Ukrainian Insurgent Army (UPA), who fought for an independent Ukraine as national heroes. ${ }^{1}$ What Ukrainians do not tend to remember are the participation of Ukrainian groups (significantly the OUN) in pogroms against the local Jewish population, collaboration with the Nazis, or the OUN's own antiSemitic policies before 1943. The exclusive nature of Ukrainian war memories is a result of many factors, the most important being that the acknowledgement of other victimhood narratives or Ukrainian participation in war crimes would undermine the Ukrainian narrative of victimization.

The most predominant of Ukrainian memories about the Second World War is the heroism of the OUN and the UPA. This view has been more popular in Western Ukraine and among the Ukrainian Diaspora than in Eastern Ukraine, but there has recently been a push to make these groups national heroes all over Ukraine. $^{2}$ The government of Ukraine drafted a bill in 2002 that would honour the OUN and UPA as heroes for their fight for independence. ${ }^{3}$ Ukrainian president 
Viktor Yushchenko established the Institute of National Memory in May 2006 to promote this interpretation of history. ${ }^{4}$ The Institute has been viewed as a 'cheap' politicization of history, enabling Yuschenko to curry favour with voters. ${ }^{5}$ It is also an attempt to unite East and Western Ukrainians in a shared heroic narrative, as a bulwark against Russian influence - because the OUN and UPA fought against the Soviet occupiers, which is why the Soviets fostered anti-OUN/UPA sentiments. $^{6}$

In his article, "Competition Among Victims: the Image of the Other in post-Soviet Ukrainian Narratives on World War II," Wilfried Jilge surveys Soviet and post-Soviet textbooks from Ukraine to compare the change of attitude in different areas of the country regarding partisan efforts in the war. Jilge identifies several temporal differences: post-Soviet textbooks identify OUN and UPA efforts to "liberate" Ukraine from the Soviet Union, while Soviet textbooks only acknowledged soldiers in the Red Army as heroes. ${ }^{7}$ Jilge goes on to study patterns in memorialization, and notices that they differ between East and West Ukraine: West Ukraine has many memorials and monuments to OUN members and UPA fighters, while these are rare in East Ukraine. ${ }^{8}$ Ultimately, Jilge concludes that regional differences are too complex 
for Ukrainians to ever accept the OUN and UPA heroes nationwide, despite attempts by current administration to achieve that end. ${ }^{9}$

What many object to in the portrayal of the OUN and UPA as heroes is that this view overlooks many of the acts that these groups committed during the Second World War. OUN has been criticized as being a group of Nazi collaborators. ${ }^{10}$ It is true that members of both factions of OUN, OUN-M led by Andrej Melnyk and OUN-B led by Stepan Bandera, were allied with the German occupiers at certain times during the war. ${ }^{11}$ OUN is even known to have had anti-Semitic policies of its own. ${ }^{12}$ Roman Shukhevych, who became the leader of UPA in 1943, was the leader of a Ukrainian-staffed, German-led Nachtigall Battalion in the early 1940s, and there has been much international debate over the extent of his participation in atrocities committed by this battalion. ${ }^{13}$ Many Ukrainians, despite international condemnation, regard Shukhevych and other OUN/UPA members with respect. ${ }^{14}$ Ukrainians defend the alliance with the Nazis by claiming that it was merely strategic, not ideological, and they deny that any fascist or antiSemitic element was present in the OUN movement. ${ }^{15}$ Ukrainian-staffed battalions (the Nachtigall was one of 3 such companies) fighting for the Nazis are explained 
as training for future UPA activity. ${ }^{16}$ Ukrainian nationalists justify so-called collaboration with Nazis because the OUN believed that the best chance for establishing an independent Ukraine was to fight the Red Army - and the Nazis gave them an opportunity to do so. ${ }^{17}$ Ukrainians saw the Nazis' plan to create a "new order in Europe" as an indication that the Germans might support an independent Ukraine, similar to the independent Slovakian state that the Nazis had set up after annexing Czechoslovakia (although it must be acknowledged that Slovakia was under Nazi influence and had a puppet government). ${ }^{18}$ For many nationalist Ukrainians, the idea that the OUN's ultimate goal was Ukrainian independence is enough to vindicate the OUN and UPA from any "collaboration" with the Nazis. ${ }^{19}$

After the Nazis turned on their Ukrainian allies and put its leaders into concentration camps, Ukrainian aggression continued. In the summer of 1943, the UPA began a "pre-meditated" program of massacres of Polish inhabitants of Volhynia and Eastern Galicia. ${ }^{20}$ Many Ukrainians claim that these massacres were a response to Polish violence, but the death toll for Poles from Ukrainian massacres is many times higher than the death toll for Ukrainians from Polish massacres. Estimates vary greatly, but they range 
from 60000 to 500000 Polish victims, compared to 15000 to 30000 Ukrainian victims. ${ }^{21}$

The dark side of Ukrainian national heroes is ignored for a few reasons. First, acknowledgement of OUN or UPA participation in such genocidal atrocities would undermine their status as national heroes. Already, there has been international pressure not to venerate such controversial figures, but this pressure has largely been ignored. ${ }^{22}$ Second, and more importantly for modern Ukraine, is that recognizing these darker events in Ukraine's history could easily upset the relationship between Eastern and Western Ukrainians.

The delicate relationship between Eastern and Western Ukrainians in regards to national history is based on their different interpretation of the "occupations" of Ukraine and related violence. Western Ukrainians regard the Red Army presence as having been an occupation, and they actively fought against them, both with and without the Nazis. Eastern Ukrainians, on the other hand, regard the Nazis as the occupiers and the Red Army as the liberators. They actively fought the Nazis, and have no interest in celebrating the OUN and UPA as heroes. Despite this difference, both Eastern and Western Ukraine share the fact that they suffered severely at the hands of their 
aggressors. Regardless of which aggressor perpetrated which crime, Ukrainians view themselves, from the East or West, as victims in general. ${ }^{23}$

One side of Ukrainian memory of the Second World War concerns their national heroes; the other side is their victimhood narrative. It is true that Ukrainians were victimized by many different groups in the twentieth century - bourgeois Poles, the Red Army and the Soviet regime, and even the Nazis with whom some Ukrainians collaborated. However, Ukrainians are not the only group with a legitimate victimhood narrative, yet they do not recognize any of these other groups' tragedies separately from the Ukrainian narrative. ${ }^{24}$ Foremost among the neglected victimhood narratives situated in Ukraine, is the Jewish Holocaust. Hundreds of thousands of Jews were murdered in what is now Ukrainian territory during the Second World War, leaving only a fraction of the number of Jews who lived there before the war. ${ }^{25}$

The Holocaust is ignored for a number of reasons. First, under Soviet rule after the war and until the 1990s, there was no discussion or even mention of the Holocaust in Ukraine. There was no recognition of victims there except for (Ukrainian) Soviet comrades who had been murdered by Nazis and the enemies of 
communism. Jewish, Ukrainian, Polish, and Russian deaths were all lumped together as Soviet casualties in the "Great Patriotic War." 26 This distortion of history (for not all such casualties were really a result of defending against the Nazis) left no precedent for acknowledging the Holocaust after Ukraine finally achieved independence in $1990 .^{27}$

Second, many of the non-Ukrainian victims whose narratives are not acknowledged in Ukraine were victims of Ukrainian aggression. ${ }^{28}$ Not all Ukrainians were perpetrators, and this is one reason that such aggression has been largely glossed over in Ukrainian memory of the Second World War. ${ }^{29}$ However, many Ukrainians participated in pogroms against their Jewish neighbours and massacred villages of Poles. To recognize these victims would be to recognize Ukrainian perpetration of atrocities, and this would invalidate the concept of Ukrainians as victims. Just as recognizing Ukrainians as perpetrators would undermine hero myths, it undermines the perception of Ukrainians in general as merely innocent civilians. This is especially the case in regards to UkrainianJewish relations, as, according to Frank Colczewski, the perception of Ukrainians as perpetrators has the potential to "perpetuat[e] distortions and resuscitat[e] 
stereotypes" of Ukrainians in general being perpetrators, not victims. ${ }^{30}$

Third, ignoring any victimhood narrative but that of Ukrainians keeps Ukrainian victimhood the focal point of Ukrainian history. Many Ukrainians feel that the international community has long ignored their suffering. ${ }^{31}$ The Holodomor, or Great Famine of 193233 has only recently been accepted by the United Nations as an act of genocide against the Ukrainians, and this was after years of campaigning by Ukrainian Diaspora groups to receive such recognition. ${ }^{32}$ Other instances of Ukrainian suffering, including Nazi oppression and retaliatory massacres by Poles, have not received much recognition - probably in light of international knowledge of Ukrainian roles in related violence against Poles and Jews. Ukrainians, on the whole, do not acknowledge OUN and UPA perpetration of war crimes, so they merely see themselves as victims of others' aggression. They cannot acknowledge other victimhood narratives, or their own will seem paltry in comparison.

Fourth, the population of Ukraine is almost entirely ethnically homogenous, there is no one left but Ukrainians to recognize other victimhood narratives. Omer Bartov has complained that almost nothing has 
been done in Ukraine to memorialize, or even simply recognize, the decimated Jewish population there. ${ }^{33} \mathrm{He}$ bemoans that commemoration of Jewish victims that lived in Ukraine has been mostly financed and put in place by Jews from abroad, not local Ukrainians. ${ }^{34}$ Bartov catalogues the numbers of Jews murdered by invaders and neighbours alike, and makes note of the almost non-existent Jewish communities in Ukraine at present. However, it is this very lack of a local Jewish community, which Bartov identifies, that has fed the neglect of the Jewish victimhood narrative in Ukraine. Ukrainians are engrossed in their own narrative, and have no Jewish neighbours to remind them of the other victims.

Finally, the focus on Ukrainian victimhood over any other groups' victimhood reinforces the notion of a shared suffering among all Ukrainians. There are divisions in regards to political and historical memory among Ukrainians in the east and west, but recently there have been efforts to overcome them. ${ }^{35}$ These efforts are dual-faceted: shared heroism, as detailed above, and shared victimhood. Despite divergent histories and different geographic areas, Ukrainians can unite under the recognition of their shared victimhood. They believe that they were targeted as an ethnic group, despite the allegiances and actions 
of Ukrainians differed greatly, even in the same regions. ${ }^{36}$ Not all Ukrainians were Nazi collaborators or murderers of Poles or Jews, just as not all Ukrainians were in the Red Army. ${ }^{37}$ As an ethnic group, they cannot relate to each other as having an identical political or military history. They can, however, relate to one another as victims of similar horrors: victimization by the Soviets first in the Great Famine, then by the Nazis during the German Operation Barbarossa, by Poles in the massacres of 1943, and again by Soviets at the end of the Second World War. To recognize that there are nonUkrainians who share in the same--if not worse, and usually larger-scale--horrors would undermine this concept of shared suffering. For example, just as Ukrainians were singled out for massacre in retaliation for massacres of Poles, Ukrainians singled out Poles. ${ }^{38}$ It is the perceived uniqueness of the Ukrainian situation that is employed by politicians to unite Ukrainians therefore acknowledging that their victimhood is not unique would limit the unifying qualities of such a narrative. ${ }^{39}$

Ukrainians have many diverse reasons for focusing on their own victim narratives. These reasons range from the ethnic homogeneity in modern Ukraine to more suspect political ambitions and an unwillingness to 
face the darker sides of Ukrainian history. Since the Soviet era ban on reference to the Holocaust, there has been a slow progression towards acknowledgment of other victim narratives. At times, this progression has been halted, especially by the occasional incorporation of Jewish victims into the wider category of "Ukrainian" by some Ukrainians. As the Ukrainian narrative becomes more widely recognized internationally and foreign scholars examine all aspects of this period, it is possible that popular Ukrainian memory will one day come to accept the co-existence of other victim narratives, without trying to compete.

${ }^{1}$ UPA is considered the military wing of the OUN, although they were separate organizations.

${ }^{2}$ The Ukrainian Diaspora refers to Ukrainians, mostly from the west part of Ukraine, who moved to North America shortly before or after the Second World War. Many retain close ties with Ukraine, and are active in organizations for the study of Ukrainian history. Johan Dietsch, Making Sense of Suffering (Lund: Media Tryck, 2006), II7.

3 Ibid., 71

${ }^{4}$ Tatiana Zhurzhenko, "The Geopolitics of Memory" Eurozine, May I0, 2007, http://www.eurozine.com/articles/2007-05-10-zhurzhenko-en.html, paragraph 6.

${ }^{5}$ Zhurzhenko, paragraph 30.

${ }^{6}$ Zhurzhenko explains the Ukrainian need to remove still-present Russian influence from their culture and politics, paragraph 10.

${ }^{7}$ Wilfried Jilge, "Competition Among Victims?: The Image of the Other in Post-Soviet Ukranian Narratives on World War II", 47-66 in Georgii Kasianov, (ed.) Obraz inshoho v susinikh istoriiakh: Mify, stereotypy, naukovi interpretatsii (2008), 49 - 56.

${ }^{8}$ Jilge, 56. 
${ }^{9}$ Ibid., 65.

${ }^{10}$ Marples provides a detailed account of John A. Armstrong's Ukrainian Nationalism, wherein Armstrong describes this collaboration and even posits that OUN ideology was of a fascist nature. David Marples, Heroes and Villains: Creating National History in Contemporary Ukraine. (Budapest, New York: Central European Press, 2007), 24.

${ }^{11}$ lbid., 24, 117

${ }^{12}$ Karel Berkhoff, Harvest of Despair: Life and Death in Ukraine under Nazi rule. (Cambridge: Belknap Press of Harvard University Press, 2004), 83.

${ }^{13}$ Notably participation in the massacres of Jews in the Lviv pogroms from June 30 to July 2, $194 \mathrm{I}$.

${ }^{14}$ International condemnation comes from many groups, but most notably the Israeli organization Yad Vashem, which focuses on issues and studies of the Holocaust.

${ }^{15}$ Zhurzhenko, paragraph 27.

${ }^{16}$ Berkhoff, 288

${ }^{17}$ Ukrainians welcomed German forces at first, thinking their situation could not be worse under German occupation than it had been under Soviet occupation. Ibid., 20.

${ }^{18}$ Ukrainian hopes in Marples, II 3.

${ }^{19}$ Ibid., 84; Jilge, 52

${ }^{20}$ Berkhoff, 286. Interestingly, Berkhoff notes that in October 1943, the new leader of the UPA, Roman Shukhevych, issued a communiqué condemning the "mutual mass-murders" of Ukrainians and Poles, and started a reconciliation program. This is the same Shukhevych who has been accused of war crimes against Jews in Lviv. Ibid., 298.

${ }^{21}$ Marples, 222-223

22 The Council of Europe requires member countries (including Ukraine) to educate young citizens about the Holocaust. President Yushchenko has claimed that this is being done, as the Holocaust is in the Ukrainian curriculum for students. However, the Holocaust is presented in terms of the general European experience, and not as part of any local, Ukrainian history. Johan Dietsch, "Imagining the Missing Neighbour: Jews and the Holocaust in Ukrainian History Textbooks,” I 95-204 in Georgii Kasianov, (ed.) Obraz inshoho v susinikh istoriiakh: Mify, stereotypy, naukovi interpretatsii (2008), 204. Pressure has also been put on Ukraine to acknowledge the Holocaust, especially by Jewish historians like Omer Bartov, and the organization Yad Vashem. Omer Bartov, "White Spaces and Black Holes: Eastern Galicia's Past and Present," 3 I8-354 in Brandon and Lower (eds.) The Shoah in Ukraine (2008). the entire text describes "missed" opportunities for memorializing the Holocaust.

${ }^{23}$ Zhurzhenko explains the different war experiences of East and Western Ukrainians and the political tactic of focusing on shared Ukrainian victimhood; paragraphs 30-34. 
${ }^{24}$ In his book Making Sense of Suffering, Johan Dietsch studies a number of Ukrainian history textbooks and discovers that most make little to no mention of Jewish victims in Ukraine - even in reference to Babi Yar, one of the most devastating massacres of Jews in Ukraine during the Second World War, I57.

${ }^{25}$ The exact number of murdered Jews is unknown; estimates range from around 500000 to almost 2 million. Omer Bartov details the difference in preand post-war populations in towns in Galicia in Erased: Vanishing Traces of Jewish Galicia in Present-Day Ukraine. (Princeton: Princeton University Press, 2007). He cites his mother's hometown of Buchach as a strong example of how thoroughly Galicia was purged of its Jewish population: at the beginning of the Second World War, there were 10000 Jewish inhabitants of the town; in July 1944, only 100 remained. Bartov lists the progress of genocidal events in the decline of the population, but does not say how many Jews emigrated from the area, as his mother's family did; I28-129

${ }^{26}$ Jilge, 47. Dietsch, Making Sense of Suffering, 164.

27 jilge, 55 .

28 In regards to Jewish victims: Dietsch, "Imagining the Missing

Neighbour," 203; in regards to Polish victims: Marples, 208.

${ }^{29}$ Frank Golczewski, "Shades of Grey: Reflections on Jewish-

Ukrainian and German-Ukrainian Relations in Galicia," I I4-I55 in Brandon and Lower (eds.) The Shoah in Ukraine (2008), I I 4.

${ }^{30}$ Golczewski, II5.

${ }^{31}$ Dietsch, Making Sense of Suffering, 120-121.

32 Interestingly, the Ukrainian community modeled their representation of the Great Famine after representations of the more famous Holocaust. Ibid., I44, 146.

${ }^{33}$ Bartov, Erased: Vanishing Traces of Jewish Galicia in Present-Day

Ukraine, the entire book. For example, pages 75, 78, 8I, 85 etc.

${ }^{34}$ Ibid., 68.

${ }^{35}$ Zhurzhenko, paragraph 30; Dietsch, 7I.

${ }^{36}$ Ukrainians see themselves as victims of discrimination, as a unifying theme. Dietsch, Making Sense of Suffering, I34.

${ }^{37}$ Golczewski, I 44.

${ }^{38}$ David Marples outlines the Ukrainian-Polish Conflict of 1943 in

Chapter 6 of Heroes and Villains. Berkhoff, $286-297$.

39 Jilge, 48. 